\title{
盛土の設計安全率決定に関する研究 DECISION METHOD OF SAFETY FACTOR IN DESIGN OF EMBANKMENT
}

\author{
長 尾 義 三*・松 尾稔** - 黒田 勝 彦*** \\ By Yoshimi Nagao, Minoru Matsuo and Katsuhiko Kuroda
}

\section{1.はじめに}

土木構造物を設計する場合，その安全率のとり方はき わめて重要な問題である。安全率の決定法に関しては従 来からいくつかの研究や提案がなされてきた。その中で 筆者らが特に注目するのは Freudenthal によって与え られた基本的な考え方である ${ }^{1,2)}$ 。すなわち, 純力学の 問題として安全率と破壊確率の関係を求める一方, 設計 に採用すべき合理的な破壊確率を力学を離れた経済的な 側面から決定し，その結果として，合理的な設計安全率 を決定しょうとする考え方である。

さて筆者らは, 地盤の強度その他のばらつきに起因す る破壊確率に着目し，地盤調查規模や設計安全率の合理 的な決定法に関して研究を行ない，その一部はすでに発 表した ${ }^{3,44,5)}$ 。本論文に执いては，具体的な対象として 盛土の設計安全率を取り上げ，主として，破壊確率を考 虑した経済的な評価モデルの提案と，これに関する試算 や実際例による種々の検討を行なっている。この場合， 明確にしておかなければならない本論文の基本的立場は 次の点である。社会的, 経済的な意味での合理性や最適 性を考慮した上で，力学的にそれに見合ったものを作る のが最もよい, と考えるのである。すなわち, 社会的, 経 済的諸条件に基ゔいてその構造物に対する最適の投資額 が本論文の方法を含む何らかの方法で求められたとき, それに対応して力学的に適正な設計条件を見出そう，と するわけである。

第 2 章で経済的に評価するためのモデルと調查や設計 との関連を明確にした上で, 第 3 章においてそのモデル を提案する。第 4 章では数值計算や実際例をもとにモデ ルの検討を行なう。なお, 本論文では, 沈下問題は一応

$*$ 正会員 工愽 京都大学教授 工学部交通土木工学科

** 正会員 工博 名古屋大学助教授 工学部附属土圧研究施設

*** 正会員工修 京都大学助手 工学部交通土木工学科
除外し, 盛土の急速破壊のみを対象とする。また, 盛土 は円孤すべり面にそって破壊することを容認することと し，破壞面の生起確率そのものについては言及しない。

\section{2. 経済的評価と調査, 設計との関連}

\section{（1） 概 説}

調查, 設計, 施工を相互に関連するシステムとしてと らえ，その中での個々の問題を解明していくことが必要 である。その意味で，詳細な評価モデルの議論に 先立 ち, 本章では, 経済的な評価と調查や設計との相互関係 を明らかにしておきたい。

\section{（2）フローチャートによる説明}

経済的な評価モデルと調査，設計との関連を，作業の 手順にしたがって図示したのが図一1である。図からも わかるように, 本研究で対象とするのは実施計画の段階 であり，構想計画等の上位計画の段階を問題にしている のではない。図にしたがって説明すると以下のとおりで ある。

a）盛土の天端高さ $H$ と天端幅 $B_{u}$ は，上位計画の 段階における路線選定および施工基面の決定時に定ま る。

b）一方, 種々の盛土実施例を対象にして第 3 章で提 案する経済的な評価モデルにより計算を行ない, 期待総 費用 $C_{T}$ を最小にするときの破壊確率 $\left(P_{F}\right)_{\mathrm{opt}}$ を求め る。これらを盛土の重要度に応じてクラス分けし，あら かじめ, それぞれの重要度に応じた $\left(P_{F}\right)_{\mathrm{opt}}$ の大体の範 囲（オーダー）を知るための表を作成しておく。

c）いま対象としている盛土の重要度に応じて，上述 した表より大体の $\left(P_{F}\right)_{\text {opt }}$ を選び出し，これを用いて 前論文 ${ }^{5)}$ で詳述した先行設計を行なう。その結果, 盛土 を建設する地盤の期待強度（盛土の破壊確率が上述の 


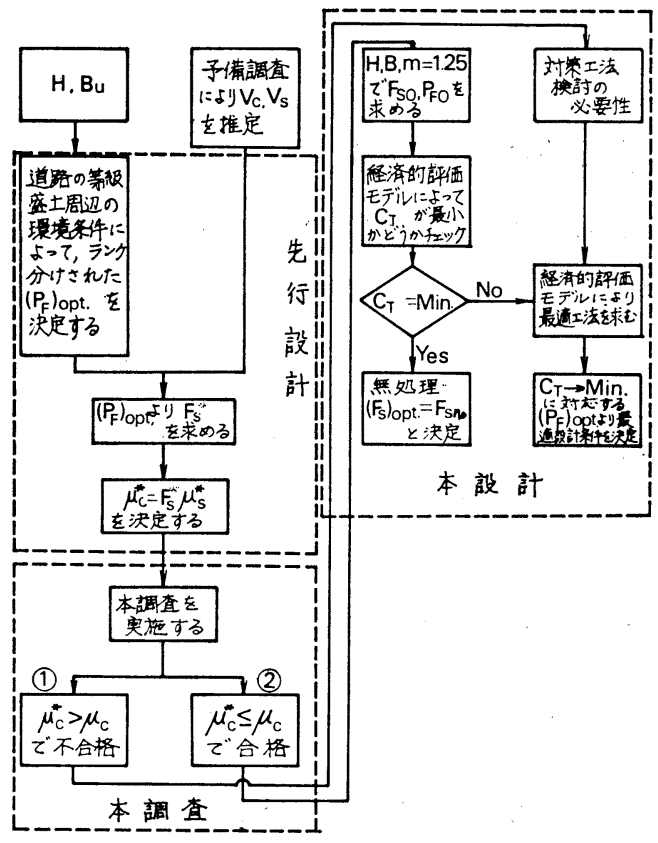

図一1 調查, 設計と評価モデルの関係

$\left(P_{F}\right)_{\text {opt }}$ 以下に押えられるために必要な地盤の強度）$\mu *$ が求まる。

d）前論文で詳述した手順に従って本調查を実施す る。本調査の結果は図一1の (1)，(2)のいずれかの場合 となる。

e）ついで本設計を行なう。本調査において $n_{0}$ 個の 力学試験 (たとえば一軸圧縮試験) 結果が得られたとす ると，その結果を用いて，地盤の母数 $(\mu, \sigma)$ を推定す る。この母数に対してすべり計算を行ない, 力学的な意 味での破壊確率 $\left(P_{F}\right)_{n 0}$ を求める。一方, 経済的な評価 モデルから, 経済的な意味での $\left(P_{F}\right)_{\text {opt }}$ と最小の期待 総費用 $\left(C_{T}\right)_{\min }$ を求める。そして $\left(P_{F}\right)_{n 0}$ と $\left(P_{F}\right)_{\text {opt }}$ とを比較する。

f) もし $\left(P_{F}\right)_{n 0}=\left(P_{F}\right)_{\mathrm{opt}}$ であるならば，実際の力 学的な破壊確率が経済的な意味での適正破壊確率に一致 している和けであるから，この地盤上に所定の盛土を地 盤改良その他の対策なしに急速施工することが可能であ り, 最適設計安全率は $\left(P_{F}\right)_{n 0}$ に対応する值 $\left(F_{s}\right)_{\text {opt }}$ と して定まる。

g）一方， $\left(P_{F}\right)_{n 0}>\left(P_{F}\right)_{\text {opt }}$ であるならば, 経済的に みてより適正な破壊確率を与える対策工が他に存在する わけであるから, 押え盛土や地盤改良などの対策を講じ て， $\left(P_{F}\right)_{\text {opt }}$ を実現することが必要となる。

h）これ以下の説明を助けるために図一2 を用いる。 この図は，費用と破壊確率の関係を模式的に表わしたも のである。もし大きな破壊確率を許容するならば，破壊 による期待損失費が大となる反面, 調査費や建設費は安

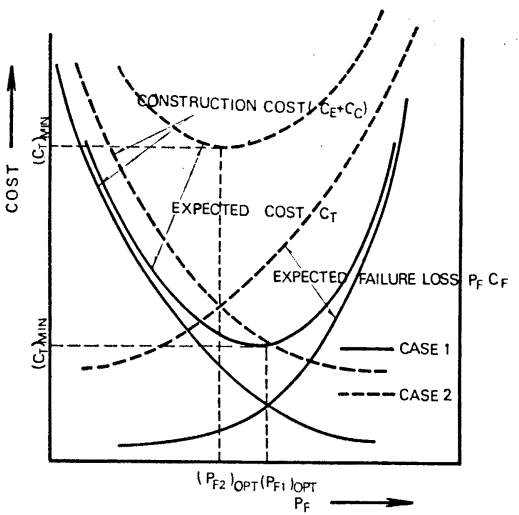

図一2 費用〜破壞確率関係の模式図

くつく。一方，小さな破壊確率に押えようとするならば 調査費や建設費は高くなるが，破壊による期待損失費は 小さくなるであろら。このことから，総費用が最小とな るような $\left(P_{F}\right)_{\text {opt }}$ が存在するに違いない。

さていくつかの対策工を考え，それぞれの対策工，あ るいはそれらの組合せに対して，たとえば図実線や点線 の総費用曲線を描くと, それぞれに対して $\left(P_{F}\right)_{\text {opt }}$, $\left(C_{T}\right)_{\min }$ が求まる。いくつかの $\left(C_{T}\right)_{\min }$ の中で最小の $\left(C_{T}\right)_{\min }$ を与える工法が最適工法となる。この理由は以 下のと拈りである。すなわち，たとえばこの盛土が道路 のためのものとすると, どのような工法で施工されよう とも, 所定の断面, 機能を有するようにでき上った後に は，その道路がもたらす便益 $B$ は不変と考えてよい。

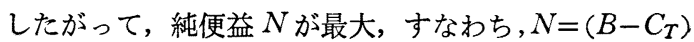
$\rightarrow \max$ を評価基準と考えたとき，これはとりもなおさ ず $\left(C_{T}\right)_{\min }$ に対応し, 結局総費用最小の手段が最適の 対策工といえるからである。なお，対策工としては，押 え盛土, 地盤改良, 盛土の斜面勾配の変化, あるいは追 加調査を行ない地盤強度の推定信頼度を増大させて破壊 確率を低減する方法，などが考えられる。

\section{（3）本設計において対象とする破壊確率}

粘土地盤上に道路のための盛土を施工する場合を例に とると, 施工中や施工直後, あるいは道路として供用を 開始した後の各時点において, 一般に地盤の強度は異な る。なぜなら, 各時点において地盤の圧密度が異なるか らである。したがって，一見，それぞれの時点における 力学的な破壊確率は異なってくるように思える。一方， 破壊損失費は各時点によって相違するから，経済的評価 モデルから求められる $\left(P_{F}\right)$ opt 当然変化する。そこ で, どの時点での破壊確率を対象にするかが重要な問題 となる。本節では，この点に関する筆者らの考え方を明 らかにする。

施工直後と供用開始後における最小安全率円上の応力 


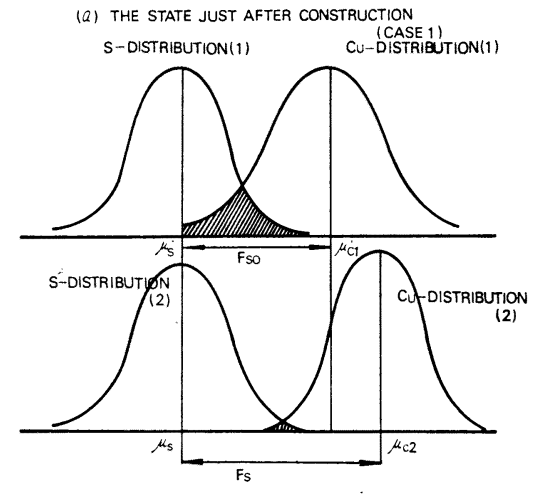

(b) THE State in SERVice (CASE 2)

図-3 せん断応力とせん断強度の分布の関係

分布と地盤強度 (たとえば非排水強度 $c_{u}$ ) の分布の相 互関係を模式的に表わしたのが図一3である。すでに発

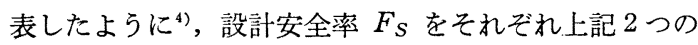
平均值の比, $F_{s}=\left(\mu_{c} / \mu_{s}\right)$ で定義し，そのときの破壊確 率を図の斜線部として考えるならば，図から明らかなよ らに，力学的には盛土が立上った施工直後が最も危険な 状態となる。したがって力学的な側面からのみ考えれば， 施工直後を対象にして破壊確率と設計安全率を考えるの が最も妥当のよらに思える。しかしながら，経済的な側 面からみた場合には，必ずしも施工直後を対象に考える のが最適とする根拠がない。

筆者らのアンケート調查によると，ある工区に扔いて 施工中あるいは施工直後にすべり破壊を生じた場合，そ の再建によって予定の全線開通，供用開始の期日が大幅 に遅れた例はきわめてまれである。いいかえれば，施工 直後に生じたすべり破壊は, 原則的に予定の供用開始期 日を遅らせることなく復旧が可能である（復旧しなけれ ばならない）と考えるのは妥当であるう。あるいはま た，たとえ供用開始が多少遅延しても，これは上位計画 における裕度として考慮されるべきもので, 道路として の便益や損失は供用開始後始めて生ずる，と考えること は許されるであろう。すなわち，道路としての機能を発 揮する以前の段階である盛土施工直後を対象にした場合 には，破壊損失費としては，その道路の全区間に対する 損失や開通後の道路機能の停止による損失などを考える 必要はない。開通前の, その盛土区間のみを対象とすれ ば十分である。この場合には, 盛土の再建費や破壊の周 辺地域に対する損害賠償などだけが問題となる。

さて, 一方, 供用開始後, 現実に車が道路上にあると きに破壊したり，あるいは幸運にも道路上に車がなかっ たとしても，この時点で破壊すると，道路の機能停止期 間に失われる経済的損失は非常に大きなものとなるであ ろう。このように考えると，供用開始後のある時点にお
ける破壊確率を対象にした方が，設計上より妥当である ようにも思える。

ところで，ここで考えなければならないのは，「盛土 の破壊」という問題が有する特殊性である。図一3 の 2 つの斜線部が原理的に何を意味するかを考えてみよう。

図（a）(施工直後）の場合の斜線部は, 強度が曲線（1） で示されるような地盤上に, 曲線 (1) で示す分布の荷重 が載荷された場合の破壊確率を示す。一方, 図（b）は 図（a）とは無関係に，もしはじめから曲線 (2) の強度 を有する地盤上に曲線 (2) の載荷が行なわれたならば, その破壊確率が斜線部となることを意味している。いい かえると, 施工直後の場合は, 図（a）の分布形を有す る $c_{u}, s$ のちち, 実際にはどのような值の組合せが実現す るかは盛り終わってみなければわからなかったわけで, その意味で, 確率的に斜線部の破壊の可能性があったわ けである。ところが，いったん現実に盛土が立上ったと すると, その時点ではすでに, ある確定した $c_{u}, s$ が実 現しており，かつ $c_{u}>s$ が確認されているわけである。 したがって, その時点ではすでに, 図（a）斜線部の破 壊確率は実際上意味のないものとなっている。すなわち 地震荷重などの突発的な荷重を考慮外にするならば，こ のようにいったん盛土ができ上ってしまうと，その後図 （a）の状態が図（b）の状態に移行して，供用開始後も なお図（b）斜線部の破壊確率が実存するわけではなく て，供用後の破壊確率はゼロと考えてよいわけである。 なぜなら，いったん実現した載荷重は施工直後と供用開 始後でほとんど変らないのに対し, 施工直後に実際に十 分であった地盤の強度は,時間の経過とともに,一般に, さらに増加しているからである。この点が, 荷重または 強度の出現が時間的に大問題となる場合, たとえば, 主 として地震荷重や風荷重に対して設計されなければなら ない吊橋や鉄塔などの場合と，盛土の場合が性質を異に する点である（もちろん盛土に関しても，地震外力など の破壊確率に及ぼす影響は実際問題として無視できず, 今後究明されなければならない課題である)。

要約すると, 盛土の場合には, 施工直後に破壊しなけ れば供用開始後に破壊することはないと考えてよく，そ の意味で施工直後の破壊確率を対象にすればよいと考え られる。そしてその場合の破壊損失費としては, 供用開 始後の損失を考慮する必要はない。筆者らの調査による と, 片盛土の場合に大沈下で舗装が割れ, そこから大雨 が浸透してすべり破壊にいたった例を除き，供用開始後 にす心゙った例はない。また，平地上の全面盛土では供用 開始後に破壊した例はない。大量の雨水の浸入は, 防水 処置として設計上考慮されるべきで, 回避できない程度 の雨水の浸透による盛土本体の重量の増加は, 当初から 載荷重のばらつきの範囲に入れて設計上考慮されるべき 
ものと考える。なお, 本論文では, 安全側の見地から, 施工中のきわめて不確実な強度増加は考慮に入れず, 舗 装を含めた盛土全体が急速に載荷されるという条件で考 えていくことにしている。

\section{3. 経斉的な評価モデルについて}

\section{（1） 概 説}

前章までに説明した基本的立場に基づき, 盛土建設に 際する期待総費用を次のように与える。

$$
C_{T}=C_{E}+C_{C}+P_{F} C_{F}
$$

ここに, $C_{T}$ は期待総費用, $C_{E}$ は地盤調查費, $C_{C}$ は 初期建設費, $C_{F}$ は破壊損失費 (再建費, 補償費, その 他) である。上式の各項は, すべて, 破壊確率 $P_{F}$ の関 数である。

目的は，上式において $C_{T}$ を最小にするような破壊確 率 $\left(P_{F}\right)_{\text {opt }}$ を求めることである。盛土自体の規模や形 状が異なればもちろんのこと，たとえ同じ工法によって 同規模の盛土を建設する場合でも，盛土の周辺条件や地 盤条件などに応じて各費用は異なる。したがって, 図一 2 の実線や点線で例示したように，いろいろな場合に応 じて費用曲線は異なり， $\left(P_{F}\right)_{\mathrm{opt}}$ の值も異なってくる。 ほとんど無限に想定されるあらゆる環境条件に対し費用 関数を決定することは不可能に近いので, ある基準值を もとに費用や破壊確率の項を無次元化して，できるだけ 簡単化できれば便利である。この目的のために，まず破 壊確率に関しては次式で定義する

$$
\zeta=\frac{P_{F}}{P_{F_{0}}}
$$

ここに， $P_{F 0}$ は，ある任意の盛土を建設する場合の基準 值で, 追加の土質調査, 押え盛土, 地盤改良などを実施 せずに, 盛土の斜面勾配 $m$ を考えられる最急の 1.25 と して 吕建設した場合（この状態を無処理状態と呼ぶこと にする）に期待される最大の破壞確率である。したがっ て, これに対応する安全率 $F_{s 0}$ は, 無処理状態におけ る安全率ということになる。さて次節以下に証明するよ うに, 式 (1) の各費用項目は $ら$ の関数として表示でき るので, 結局式 (1) は次のようにかける。

$$
C_{T}(\zeta)=C_{E}(\zeta)+C_{C}(\zeta)+\zeta C_{F}(\zeta)
$$

式 (3) において $\zeta=1.0$ ，すなわち $P_{F}=P_{F 0}$ に対す る期待総費用 $C_{T}$ は $C_{T}$ の初期值, 寸なわち無処理状 態の費用を表わしている。そこで費用項目に関しては, 次式で定義する $\eta$ を考えていくことにする。

$$
\eta(\zeta)=\frac{C_{T}}{C_{T 0}}=\frac{C_{E}(\zeta)+C_{C}(\zeta)}{C_{T 0}}+\frac{\zeta C_{F}(\zeta)}{C_{T 0}}
$$

上式で $\zeta=1.0$ とのきは， $\eta(\zeta)=1.0$ となる。このよう に, $\zeta, \eta(\zeta)$ で表示すると, 次節以下に示すように, 各 費用関数が大幅に簡単化される。

総費用関数の形は, 無処理の状態を基準にして, 種々 の対策工, すなわち追加調查, 斜面こう配の変更, 押え 盛土, 地盤改良, あるいはそれらの組合せに応じて, ど のように変化するかを明確にした上で決定されなければ ならない。費用関数 $C_{E}(\zeta), C_{C}(\zeta), \zeta C_{F}(\zeta)$ を決定す るときに基本的に重要なことは，それらが力学的な諸条 件を十分考慮した上で決定されたものでなければならな い, ということである。その意味で, 次節以下の費用関 数の決定においては, 土質力学的な考察が基礎となって いる。すなわち, 土質工学的に考慮しなければならない 種々の環境条件, たとえば盛土の断面, 荷重や地盤強度 の変動倸数, 破壊確率や安全率の初期值 $\left(P_{F 0}, F_{s 0}\right)$ など の, 実現可能な範囲にわたって, 関数形を確かめなけれ ば意味がない。そのために, 表一1に示すような各条件 を組合せて, 膨大な計算を実施した。環境条件を表のよ うに限定した理由は, 必要に応じて各節で説明するが, たとえば追加調查の項で $F_{s 0}=0.6 \sim 1.6$ の範囲を選ん だのは次の理由による。追加調査を対策工とする場合, 非常に多くの追加調查によって精度を高めたとしても, 期待できる安全率の上昇は $0.1 \sim 0.2$ 程度であり, 最大 でも 0.3 を越えないことが多数の計算結果からわかった

\begin{tabular}{|c|c|c|c|c|c|c|c|}
\hline \multirow{4}{*}{$\begin{array}{c}\text { 追加調查 } \\
(360 \\
\text { ケース) }\end{array}$} & $V_{c}$ & 0.1 & 0.3 & 0.5 & & & \\
\hline & $V_{s}$ & 0.02 & 0.04 & 0.06 & 0.08 & & \\
\hline & $n_{0}$ & 10 & 20 & 30 & 50 & 70 & 90 \\
\hline & $F_{s 0}$ & 0.6 & 0.8 & 1.0 & 1.2 & 1.4 & 1.6 \\
\hline \multirow{5}{*}{$\begin{array}{l}\text { 斜面勾配 } \\
\text { 化 } \\
(760 \\
\text { ケース) }\end{array}$} & $D / H$ & 1.0 & 2.0 & 3.0 & 4.0 & & \\
\hline & $H$ & 5.0 & 6.0 & 7.0 & 8.0 & & \\
\hline & $V_{c}$ & 0.1 & 0.3 & 0.5 & 0.7 & & \\
\hline & $V_{s}$ & 0.02 & 0.04 & 0.06 & 0.08 & & \\
\hline & $F_{s 0}$ & 0.6 & 0.8 & 1.0 & 1.2 & & \\
\hline \multirow{3}{*}{ 押元盛土 } & $D / H$ & 1.0 & 2.0 & 3.0 & 4.0 & & \\
\hline & $H$ & 5.0 & 6.0 & 7.0 & 8.0 & & \\
\hline & $H^{\prime} / H$ & 0.1 & 0.3 & 0.5 & 0.7 & 0.9 & \\
\hline \multirow{3}{*}{$\begin{array}{l}(2880 \\
\text { ケース) }\end{array}$} & $V_{c}$ & 0.1 & 0.3 & 0.5 & & & \\
\hline & $V_{s}$ & 0.02 & 0.04 & 0.06 & 0.08 & & \\
\hline & $F_{s 0}$ & 0.6 & 0.8 & 1.0 & 1.2 & & \\
\hline \multirow{4}{*}{$\begin{array}{c}\text { 地盤改良 } \\
(240 \\
\text { ケース) }\end{array}$} & $B_{s} D_{s}$ & 300 & 600 & 900 & 1200 & 1500 & \\
\hline & $V_{c}$ & 0.1 & 0.3 & 0.5 & & & \\
\hline & $V_{s}^{\prime}$ & 0.02 & 0.04 & 0.06 & 0.08 & & \\
\hline & $F_{s 0}$ & 0.6 & 0.8 & 1.0 & 1.2 & & \\
\hline
\end{tabular}
ので, $F_{s 0}<0.6$ の場合は工学的に実際的な意味がない (他の対策工が有利なことが自明)。また $F_{s 0}=1.6$ の

表一1 計算のための幾何的, 力学的条件 
表一2 賚用項目の分類

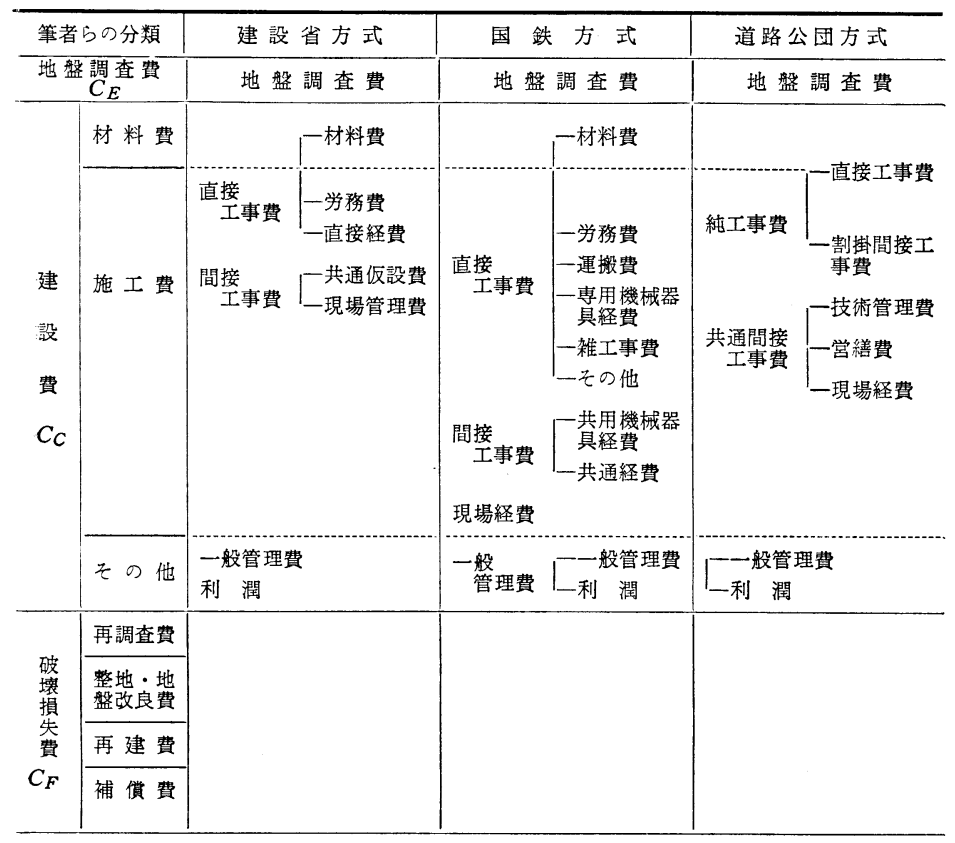

うる。

本論文では, 粘土層上の盛土の急速 破壊を考えている。したがって，本調 査としては，一軸あるいは非圧密非排 水三軸圧縮試験が実施されるものとす る。すでに提案したように市，逐次確 率比検定法の応用などによって, 本調 查段階で $n_{0}$ 個の土質試験が行なわれ たものとする。このとき, 粘土の非排 水強度 $c_{u}$ の母平均值 $\mu_{c}$ の $(\alpha / 2) \%$ 信頼下限值 $\mu_{c}\left(n_{0}\right)$ は, 標準偏差 $\sigma_{c}$ が既知の場合には，

$$
\mu_{c}\left(n_{0}\right)=\mu_{c}-\frac{\sigma_{c}}{\sqrt{n_{0}}} z_{\alpha / 2}
$$

で与えられる5)。ここに $z_{\alpha / 2}$ は, 標 準正規積分において確率が $(\alpha / 2)$ にな るときの積分下限值である。また, こ れに対応する破壊確率 $P_{F 0}$ は次式で 与えられる。

ときは, 追加調査で安全率を 1.8 前後にまで上昇できる から，一般に工学的にはこれで十分である。次節以下に おいては，表一1 のすべての組合せに関する結果を説明 することはできないので, 代表的な例（表の太線わく内 の条件の全組合せ）に関して計算例をあげ，費用関数の 誘導とその意味を説明する。

なお, 見積りや積算に関しては種々の方法がある。本 論文で取上げる費用項目と二，三の代表的な積算法 ${ }^{7), 8}$ による項目との対応は表一2 亿示すとおりである。筆者 らの費用項目の分け方は, 一見, 大分類的に過ぎるよう にみえるが，詳細な項目別費用をまとめて一括表示すれ ばよいわけで，実際的な意義が損われることはまったく ない。また，費用関数形を決定する上では，これ以上項 目を細かくすることは，いたずらに複雑化するだけで実 益は何もない。

\section{（2）地盤調查費と破壊確率}

地盤調查費 $C_{E}$ には, 先行調查費 $C_{E p}$ および本調 查費と追加調查費の和 $C_{E n}$ が含まれる（先行調査, 本 調査の定義, 目的, 実施法などについてはすでに発表し $\left.た^{4) 5}\right)$ 。計算の便宜上，すべての環境条件が同一である とみなしらる盛土区間，すなわち，一律に取扱える1ブ ロックの盛土区間に関して, 費用は, 盛土の単位長さ当 りに換算して表わす。地盤調查費は, 通常, 全建設費の $2 \%$ 前後のようであるが, 試験個数 $n$ は $\zeta$ に対してき わめて敏感であるので， くを低下させるための対策とし て, $n$ を増加させることが最適の選択となることがあり

$$
\left.\begin{array}{l}
P_{F_{0}}=\int_{K_{0}}^{\infty} e^{-t^{2} / 2} d t \\
K_{0}=\frac{\mu_{c}\left(n_{0}\right)-\mu_{s}}{\sqrt{\sigma_{c}{ }^{2}+\sigma_{s}^{2}}}=\frac{\left(F_{s 0}-1\right)}{\sqrt{\left(F_{s 0} V_{c}\right)^{2}+V_{s}^{2}}}
\end{array}\right\} \cdots
$$

ここに， $\mu_{s}, \sigma_{s}$ は地中で動員されているせん断応力 $s$ の平均值と標準偏差, $V_{c}, V_{s}$ はそれぞれ $c_{u}, s$ に関す る変動係数, $F_{s 0}=\mu_{c}\left(n_{0}\right) / \mu_{s}$ である。

さて, 無処理状態で盛土を急速施工することが無理で あることがわかり，その対策法として，試験精度を高め るために地盤調查を追加することにしたとする。いま， 試験個数を $n_{1}$ 個追加して総数 $n=\left(n_{0}+n_{1}\right)$ 個の結果 を得たとすると， $\mu_{c}$ の $(\alpha / 2) \%$ 信頼下限值 $\mu_{c}(n)$ と そのときの破壊確率 $P_{F}$ は, それぞれ式 (7), (8) で与 えられる。

$$
\begin{aligned}
& \mu_{c}(n)=\mu_{c}-\frac{\sigma_{c}}{\sqrt{n}} z_{\alpha / 2} \\
& P_{F}=\int_{K}^{\infty} e^{-t^{2} / 2} d t \\
& \left.K=\frac{\mu_{c}(n)-\mu_{s}}{\sqrt{\sigma_{c}{ }^{2}+\sigma_{s}{ }^{2}}}=\frac{\left(F_{s}-1\right)}{\sqrt{\left(F_{s} V_{c}\right)^{2}+V_{s}^{2}}}\right\}
\end{aligned}
$$

ここに, $F_{s}=\mu_{c}(n) / \mu_{s}$ で, $n$ 個の試験結果に基づいて 設計した場合の最小安全率である。式 (5)，(7) より, $F_{s}$ を $F_{s 0}$ で表わすことができ，これを式 (8) に用い ることによって，

$$
\begin{aligned}
& P_{F}=\int_{K}^{\infty} e^{-t^{2} / 2} d t \\
& K=\left\{\left(\frac{\sqrt{n n_{0}}-\sqrt{n_{0}} V_{c} z_{\alpha / 2}}{\sqrt{n n_{0}}-\sqrt{n} V_{c} z_{\alpha / 2}}\right) F_{s 0}-1\right\} \mid
\end{aligned}
$$




$$
\sqrt{\left(\frac{\sqrt{n n_{0}}-\sqrt{n_{0}} V_{c} z_{\alpha / 2}}{\sqrt{n n_{0}}-\sqrt{n} V_{c} z_{\alpha / 2}} F_{s 0} V_{c}\right)^{2}+V_{s}^{2}}
$$

したがって, 式 (2) で定義された $ら$ は, 式 (9) と式 (6) の比で与えられることになる。

一方, $n$ 個の試験に必要な調査費 $C_{E n}$ は, 次のよう に表わしてよいであろう。

$$
C_{E n}=\frac{1}{l_{e}}\left(a_{e} n+b_{e}\right)
$$

ここに, $a_{e}$ は土質試験 1 個当りの単価, $b_{e}$ はサンプリ ングその他に要する費用, $l_{e}$ は調査区間の長さである。

表一1 の太線わく内のケースについて計算結果を示 す。 $V_{c}=0.3, V_{s}=0.04$ という值は, 普通の粘土地盤 上に通常の精度で盛土が施工された一般的な場合に相当 (5),9),10),11),12),$n_{0}=30$ とい5のも常識的な例である。 $F_{s 0}$ の範囲については前節で説明した。さて, $n_{0}=30$ か ら $n_{1}$ を 10 個単位で増加させて $n=120$ に至るまでの

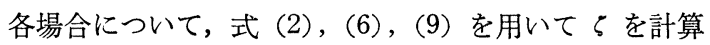
し，その結果を $n \sim \zeta$ 関係として両対数紙上に描いたの が図一4である。ここで $F_{s 0}$ をパラメーターにとった のは, 盛土の規模や, その他の環境条件によって, たと え初期の試験個数 $n_{0}$ が同一であっても $F_{s 0}$ は当然異な ってくるからである。図-4をみれば， $n \sim \zeta$ 関係は両 対数紙上でなめらかな曲線関係になっている。このよう な場合は, $F_{s 0}=0.8$ に関して図中に例示したように, 平 均法を用いた簡単な計算によって $C_{e}$ を適当に定めるこ とにより,きわめて高い精度で,

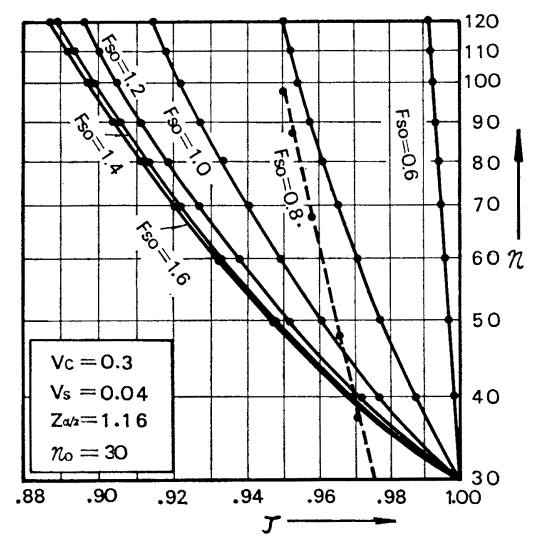

図-4 nと $\zeta$ の関係 (追加調查)

$$
\log \left(n-C_{e}\right)=\log A_{e}+B_{e} \log \zeta
$$

なる直線関係にかけることは周知である。すなわち, $n=A_{e} \zeta^{B_{e}}+C_{e}$

で表わせることがわかる。この関数形が, 表一1 のすべ ての組合せに関して確認されたことはいうまでもない。 上例に関する $A_{e}, B_{e}, C_{e}$ の計算結果を 表一3 中に示

\begin{tabular}{|c|c|c|c|c|}
\hline & $F_{s 0}$ & A & B & $\mathrm{C}$ \\
\hline \multirow{6}{*}{$\begin{array}{l}\text { 追加調查の場 } \\
\text { 合 } \\
\qquad\left(n_{0}=30\right)\end{array}$} & 0.6 & 17.78950 & -219.35435 & 12.21050 \\
\hline & 0.8 & 13.71430 & -38.86358 & 16.28570 \\
\hline & 1.0 & 12.84360 & -23.06201 & 17.15700 \\
\hline & 1.2 & 12.02273 & -19.36335 & 17.97727 \\
\hline & 1.4 & 11.25000 & -18.59938 & 18.75000 \\
\hline & 1.6 & 10.52174 & -13.63072 & 19.47826 \\
\hline \multirow{4}{*}{$\begin{array}{l}\text { のり勾配を変 } \\
\text { えた場合 }\end{array}$} & 0.6 & -2.8816 & 48.85757 & 4.2296 \\
\hline & 0.8 & -3.5468 & 6.43167 & 4.8565 \\
\hline & 1.0 & -3.6972 & 3.68259 & 4.9838 \\
\hline & 1.2 & -4.0887 & 2.64045 & 5.3813 \\
\hline \multirow{4}{*}{$\begin{array}{l}\text { 押え盛土をし } \\
\text { た場合 }\end{array}$} & 0.6 & -128760.0 & 17.42402 & 1789800 \\
\hline & 0.8 & -188510.0 & 3.46610 & 2002820 \\
\hline & 1.0 & -203130.0 & 2.12365 & 2097400 \\
\hline & 1.2 & -204290.0 & 1.87629 & 2081100 \\
\hline \multirow{4}{*}{$\begin{array}{l}\text { 地盤改良をし } \\
\text { た場合 }\end{array}$} & 0.6 & $-12.650 \times 10^{5}$ & 0.56122 & $12.320 \times 10^{5}$ \\
\hline & 0.8 & $-15.716 \times 10^{5}$ & 0.39632 & $15.230 \times 10^{5}$ \\
\hline & 1.0 & $-24.499 \times 10^{5}$ & 0.19026 & $23.776 \times 10^{5}$ \\
\hline & 1.2 & $-40.623 \times 10^{5}$ & 0.10174 & $39.840 \times 10^{5}$ \\
\hline
\end{tabular}

表一3 賞用関数の係数一覧表 $C(\zeta)=C+A \cdot \zeta^{B}$

す。

式（11）を式（10）に用いれば, 目的とする地盤調査 費と破壊確率の関係が次のように求められる。

$$
\begin{aligned}
C_{E}= & C_{E p}+C_{E n}=C_{E p}+\frac{1}{l_{e}} \\
& \times\left\{a_{e}\left(A_{e} \zeta^{B_{e}}+C_{e}\right)+b_{e}\right\} .
\end{aligned}
$$

上式の $b_{e}$ は $n$ に関係するが，変動範囲は小さいので, 実際には, 実績をもとに $n$ の範囲に応じて選択すれば よい。

\section{（3）建設費亡破壊確率}

建設費 $C_{c}$ には, 盛土本体や押え盛土の建設費, 地盤 改良のための費用などが含まれる。建設費と破壊確率の 関係を考える場合, 基準となる建設費と, 破壊確率をさ らに減少させるための対策工に関する追加建設費に区別 して考えるのが便利である。基準となる建設費 $C_{c 0}$ と しては， $n_{0}$ 個の本調查結果に基づく無処理状態の建設 費, すなわち, 路体, 路床, 路盤, 舗装からなる盛土本 体 $(m$ は 1.25) の材料費と施工費, および盛土建設に 際する直接, 間接的な諸経費との和を, 盛土の単位長さ 当りに換算して考える。この場合, 予定の盛土底面幅に 必要な土地は, 上位計画の段階で「盛土」に決定された ときに当然確保されるべきものであるから，これに要す る用地費は基準建設費に組入れて考えるのが妥当であ る。これに対し，破壊確率を小さくする，Wいかえる と, 安全率上昇の目的で $m$ を大きくしたり，押え盛土 をしたり，地盤改良をしたりするために必要な建設費は 追加建設費である。個々の場合の追加建設費に関し，以 下に関数形を求める。

a） 斜面勾配 $m$ を変化させる場合 


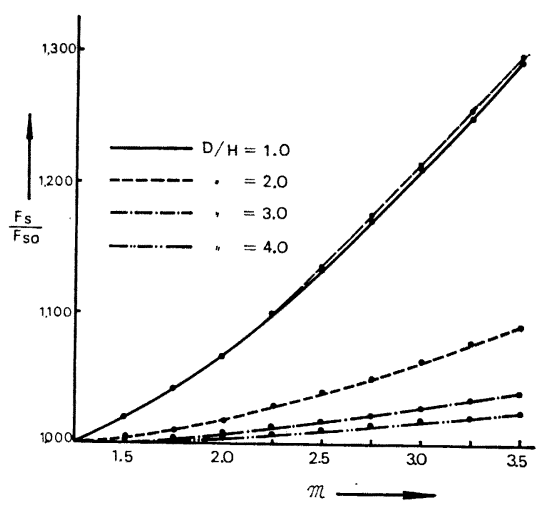

図一5 $\boldsymbol{m}$ と $\left(\boldsymbol{F}_{s} / \boldsymbol{F}_{s 0}\right)$ の関係

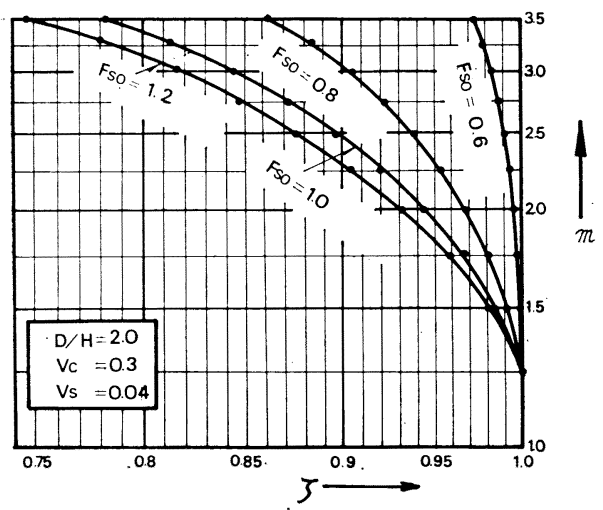

図一～$m$ と $\zeta$ の関係 (斜面勾配変化)

表一1の全組合せ条件について安定計算を実施した結 果, 粘土層の厚さ $D$ と盛土高さの比 $(D / H)$ が一定な らば, 個々の $D$ や $H$ の值にかかわらず, $m$ と ( $F_{s} /$ $\left.F_{s 0}\right)$ がほぼ完全に $1: 1$ に対応することが明らかとな った。表一1の太線内の各条件を組合せたケースに関し て，この関係を図示したのが図一5である。 $\left(F_{s} / F_{s 0}\right)$ は 一義的に $\zeta$ に変換されるから, この関係は $m \sim \zeta$ 関係 を求める上で重要な示唆を与えている。 $(D / H)$ を固定 して両者の関係を両対数紙上にプロットした例が 図一6 である。(D/H) が 2.0 以外の場合や表一1 の他の条 件の場合にも同様の関係が得られている。さて, 図一6 から，前節で説明したのと同じ理由により，(D/H) を 一定とした場合の $m$ と $\zeta$ の関数形が

$$
m=A_{m} \zeta^{B_{m}}+C_{m}
$$

の形で表わせることが明らかである。係数 $A_{m}, B_{m}, C_{m}$ を決定した例を表一3 中に示す。

一方, 斜面勾配を基準值である 1.25 から $m$ にした 場合の追加建設費 $C_{c m}$ は, 簡単な幾何学計算により,

$$
\begin{aligned}
C_{c m}= & 1.5 H\left(0.5 b_{c m} H+a_{c m}\right) \\
& +2 m H\left(a_{c m}+0.5 b_{c m} H\right) .
\end{aligned}
$$

Łなる。ここに $a_{c m}$ は $m$ を大きくしたために必要と
なった土地の単位面積当りの用地費, $b_{c m}$ は同じ理由で 必要となった盛土部分の単位体積当りの材料費と施工費 である。式 (13) を式（14）に用いることにより，斜面 勾配を変化させる場合の全建設費と破壊確率の関係が次 のように求められる。

$$
\begin{aligned}
C_{c}= & C_{c 0}+C_{c m}=C_{c 0}+1.5 H\left(0.5 b_{c m} H+a_{c m}\right) \\
& +2 H\left(a_{c m}+0.5 b_{c m} H\right)\left(A_{m} \zeta^{B_{m}}+C_{m}\right)
\end{aligned}
$$

b）押え盛土をする場合

押え盛土のための追加建設費 $C_{c p}$ は次のように表わ せる。

$$
\left.\begin{array}{l}
C_{c p}=2 B^{\prime}\left(a_{c p}+b_{c p} H^{\prime}\right)=2 a_{c p} B^{\prime}\left(1+k_{p} H^{\prime}\right) \\
k_{p}=\left(b_{c p} / a_{c p}\right)
\end{array}\right\}
$$

ここに， $B^{\prime}, H^{\prime}$ はそれぞれ押え盛土の幅と高さ, $a_{c p}$ は押え盛土のために必要な単位面積当りの用地費, $b_{c p}$ は単位体積当りの押え盛土の材料費と施工費, $k_{p}$ は押 え盛土のコストインデックスである。

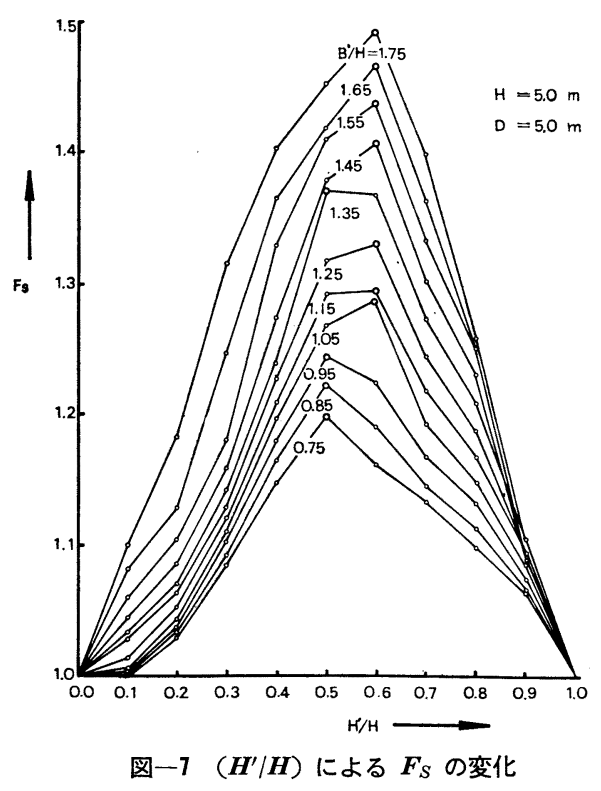

押え盛土の斜面勾配は盛土本体の勾配に一致させるも のとして, 多数の安定計算を実施した。最小の安全率 $F_{S}$ と盛土本体の高さ $H$ に対する $H^{\prime}$ の比 $\left(H^{\prime} / H\right)$ との関係の例を示したのが 図一7 である。この図は, $(D / H)=1.0$ の場合で, $\left(B^{\prime} / H\right)$ をパラメーターとして 描いてある。困は, $\left(H^{\prime} / H\right) \fallingdotseq 0.5$ 程度において最小安 全率が最も大きくなるという興味深い結果を示してい る。すなわち, 押え盛土の高さが盛土本体の高さの半分 以上になると, 力学的な安定度はかえって低下してく る。この傾向は, 図一7 の場合を含むすべての底面破壊 の場合に認められた。一方， $(D / H)$ が大きくなり，か 
つ $H^{\prime}>0.5 H$ になると層内すべりを生ずるケースがで てくる。この場合には, 図一7に示すようなきれいな傾 向は認められないけれども, $\left(F_{s} / F_{s 0}\right)$ が $H^{\prime}=0.5 H$ の ときの值よりも大きくなることがほとんどないことを確 かめた。以上の結果だけからすれば，数多くのケースの 中で力学的に最も安定度の高い $H^{\prime}=0.5 H$ の場合に関 してのみ費用関数を検討すればよいように思えるが, 建 設費もあわせ考慮すると, 力学的に最適な条件が，必ず しも経済的に最も有利な状態になりえないかも知れな い。この理由は, 斜面勾配変化の場合のように費用関数 が1変数 $(m)$ のみによって定まるのではなく, $B^{\prime}, H^{\prime}$ の 2 変数を含み, かつ $B^{\prime}\left(a_{c p}+b_{c p} H^{\prime}\right)$ といら関数形が 力学量, たとえば転倒モーメントなどと 1:1 に対応し ないからである。したがって費用関数を求める場合，い
かなる $H^{\prime}$ を対象にすればよいかを，まず明らかにし ておかなければならない。

式 (16) で求めた $C_{c p}$ と $\left(F_{s} / F_{s 0}\right)$ の関係を図示し た例が図一8である。ここにあげた例は，表一1の太線 内の場合である。 $C_{c p}$ の計算に際しては，実際にありら る場合という意味で, $a_{c p}=1000,3000,5000\left(\right.$ 円 $\left./ \mathrm{m}^{2}\right)$, $b_{c p}=100,200\left(\right.$ 円 $\left./ \mathrm{m}^{3}\right)$ を用( ${ }^{8), 13)} ， k_{p}$ を種々変化さ せた。図をみれば，予想されたように，同一の費用に対 して $H^{\prime} / H$ が異なれば力学的に到達しらる $\left(F_{s} / F_{s 0}\right)$ が. 変ってくることがわかる。しかし図（b）をみればわか. るように， $H^{\prime}>0.5 H$ (この場合は層内すべり）になる と, ごく初期の部分を除いて, 建設費の増大にもかかか， らず, $\left(F_{s} / F_{s 0}\right)$ は大幅に減少してくる。このことは, $H^{\prime}>0.5 H$ の場合を問題にする必要はなく, $H^{\prime} \leq 0.5 H$ の範囲内で検討すればよいことを意味し ている。

さて，4 枚の図を比較すればわかるよ らに, $k_{p}$ の值が小さい範囲では, $H^{\prime} \doteqdot$ $0.5 \mathrm{H}$ といら力学的に最適である状態が 同一の費用で最大の安全率上昇をもたら， す, すなわち, 経済的にも最適条件とな: っている。一方, 地価が非常に安かった り,また土材料の特別の買収や遠方から の運搬などによって $b_{c p}$ が地価に比べて かなり高くなるような場合（ $k_{p}$ が大） には，経済的に最も有利な条件は $H^{r}$ $<0.5$ Hの範囲に現われてくる(図(d))。 以上のことから， $k_{p}$ の大きさによって， 力学条件 $\left(H^{\prime} / H\right)$ の選択を行なわなけ ればならない。図にかかげていない場合 も含めて多数のケースについて検討し た。その結果, $k_{p}<(1 / 15)$ の場合には. $H^{\prime}=0.5 H$ が経済的にも最適条件とな るが (図 (a), (b) 参照), (1/15)ぐら. いを境にして逆転し， $k_{p}$ がそれ以上に なると, 一般に, $H^{\prime}=(0.3 \sim 0.4) H$ が. 最も有利な条件になるようである（図 (c), (d) 参照)。

$\left(F_{s} / F_{s 0}\right)$ を $\zeta$ に変換し, $H^{\prime}=0.5 H^{\prime}$ として $C_{c p} \sim \zeta$ 関係を両対数紙上で描い た例が 図一9である。図（a）は $k_{p}=$ (1/25), 図 (b) は $k_{p}=(1 / 15)$ とした場 合である。図から明らかなように， $C_{c E}$ 〜 関係は次式で表わすことができる。

$$
C_{c p}=A_{p} \zeta^{B_{p}}+C_{p}
$$

$k_{p}>(1 / 15)$ の場合も, 式（17）の基本. 的な関数形はまったく変らないことが確:

図一8 $\boldsymbol{C}_{c p}$ と $\left(\boldsymbol{F}_{s} / \boldsymbol{F}_{s 0}\right)$ の関係 


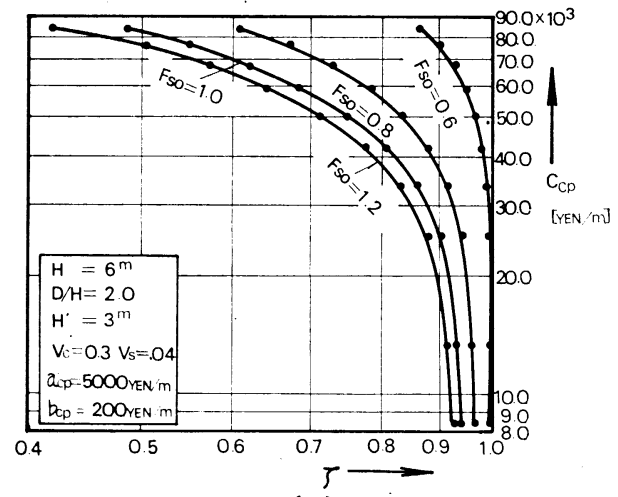

(a)

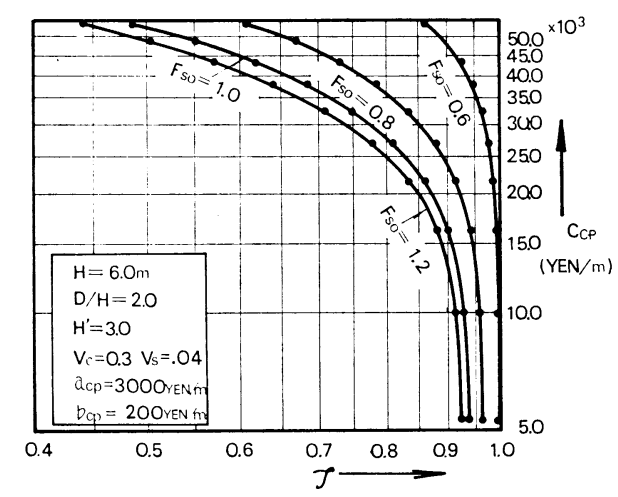

(b)

図一9 $C_{c p} \sim \zeta$ 関係（押え盛土）

かめられている。以上のことから，押え盛土をする場合 の全建設費と破壊確率の関倸は,

$$
C_{c}=C_{c 0}+C_{c p}=C_{c 0}+\left(A_{p} \zeta B_{p}+C_{p}\right)
$$

となる。 $k_{p}=(1 / 25)$ に関する $A_{p}, B_{p}, C_{p}$ の計算例を 表一3 に示した。

c）地盤改良を実施する場合

種々の地盤改良工法があるが, 盛土の場合最も一般的 なのは, サンドドレーン工法とサンドコンパクションパ イル工法であろう。本論文においては, 最初の試みとし て最も簡単な場合を取上げるといら意味から, 一挙に立 上る盛土の急速破壊を対象としており, 圧密を考慮した 盛土の段階施工などは考えていない。そこでここでは, サンドドレーン工法ではなく, サンドコンパクションパ イルを用いて地盤改良する場合を考える。

筆者の一人は, 締固め砂ぐいを含む粘土地盤の安定計 算法を提案し ${ }^{14)}$, 室内実験によってこれを検証したが ${ }^{15)}$, 実際の破壊例との対比検討は少ない。さらに, この方法 では計算がかなり複雑になる。そこで本論文では, 複合 地盤に関する厳密な力学計算は行なわず, 精度的にはや や問題があるがより工学的な見地から, 現地における過 去の実績を基礎にして考察を進めることにする。

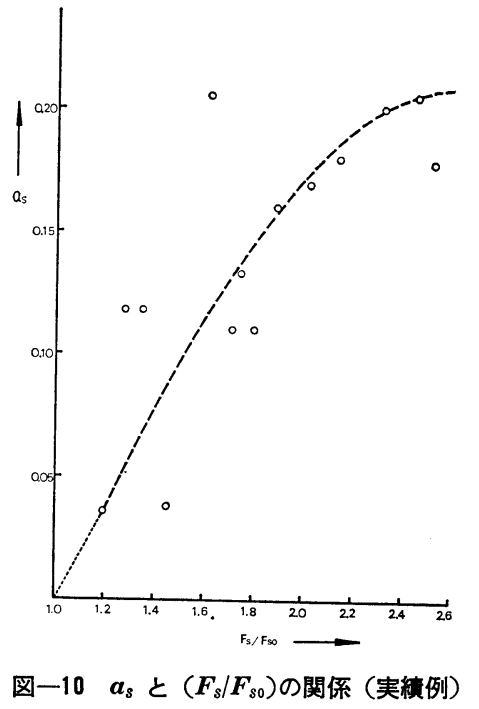

図一10 は，公表された実績(列备),17)，18) をもとにして, $a_{s}$ と $\left(F_{s} / F_{s 0}\right)$ の関倸をプロットしたものである。こ こで $a_{s}$ は砂置換率と呼ばれるもので, 対象とする改良 部分の全面積に対する全砂杭断面積の比である。また, $F_{s 0}$ は改良後の安全率で, 押え盛土を併用しなかった実 績例のみをプロットしてある。複合地盤における地盤強 度の上昇は, 正しくは, 砂杭周辺粘土の圧密による強度 増加と砂杭自体のせん断強度によってもたらされる。し かし便宜上, これを粘土の非排水強度の上昇といら形に おきなおせば，一応いままでと同じやり方で， $\left(F_{s} / F_{s 0}\right)$ の変化をらの変化に写し代えることができる。しかし， 精度的には問題があるといわざるをえない。さらに, 図 -10の $F_{s}$ 自体, 圧密度 50～90\% を考慮したものが ほとんどである。上述したような理由により, 以下に導 かれる関係は, 追加調査や本節 a), b) の場合に比べる とやや粗雑であるといわざるをえない。しかし複合地盤 に関する設計法や実績に関していまだ確固たる定説がな い現在, やや粗雑ではあっても, その基本的な関数形を 見出すことこそ重要であり, 将来その係数の精度を高め ることが必要であると考える。

さて, 地盤改良に要する費用は， $a_{s}$ と改良深度に影 響される。砂杭の直径 $d_{s}$, 砂杭部分の全面積 $A_{s}$, 盛土 の横断面における改良幅 $B_{S}$, 盛土の長手方向の改良部 分の長さ $l_{s}$, 砂置換率 $a_{s}$, 改良深度 $D_{s}$, 砂杭の打設本 数 $n^{\prime}$, 砂杭施工単位長当りの費用 $a_{c s}$, 盛土の単位長さ 当りに換算した総改良費を $C_{c s}$ とすると, 次式が成立 D。

$$
\left.\begin{array}{l}
a_{s}=A_{s} / B_{s} l_{s} \\
n^{\prime}=A_{s} / \pi\left(d_{s} / 2\right)^{2} \\
C_{c s}=a_{c s} n^{\prime} D_{s} / l_{s}
\end{array}\right\}
$$

式（19）を整理すると次式が求められる。 


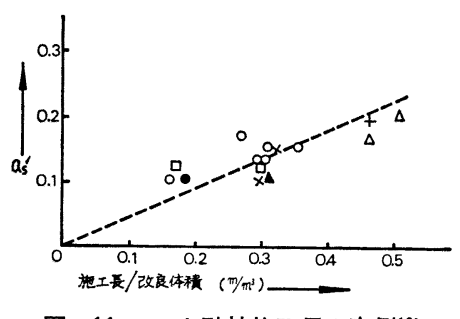

図-11 $a_{s}$ と砂杭施工長の実例 ${ }^{19)}$

$$
C_{c s}=\frac{a_{c s} B_{s} D_{s}}{\pi\left(d_{s} / 2\right)^{2}}
$$

ところで 図一11 は, 改良体積当りの砂杭の施工長 $\left(n^{\prime}\right.$ $\left.D_{s} / B_{s} D_{s} l_{s}\right)$ と $a_{s}$ の関係を示す実績例である ${ }^{19)}$ 。両者 の関係はほぼ直線とみなしらる。ところで式 (19) から，

$$
\frac{n^{\prime} D_{s}}{B_{s} D_{s} l_{s}}=\frac{a_{s}}{\pi\left(d_{s} / 2\right)^{2}}
$$

が求められ，これは， $d_{s}$ 一定の場合の $\left(n^{\prime} D_{s} / B_{s} D_{s} l_{s}\right) \sim$ $a_{s}$ の直線関係を示している。このことから, 図一11の 実際例は式（20）を支持しているといえる。

図一10 で $a_{s}$ と $\zeta$ の関係がつき, 式 (20) で $C_{c s}$ と $a_{s}$ の関係が与えられたので, $C_{c s}$ と $\zeta$ の関係を求める ことができる。しばしば起こりうる例として, 表一1の 太線内のケースについての計算例を 図一12 に示す。こ の例では，式 (20) の $d_{s}$ を $0.6 \mathrm{~m}$ にしてある。また 文献 20) に上れば, $a_{c s}$ は普通 1800 2000(円/m) であることが示されているので，計算には $a_{c s}=1900$ （円/m）を用いた。図一12 をみれば明らかなように， $C_{c s}$ と $\zeta$ は次の関数形で表わせることがわかる。

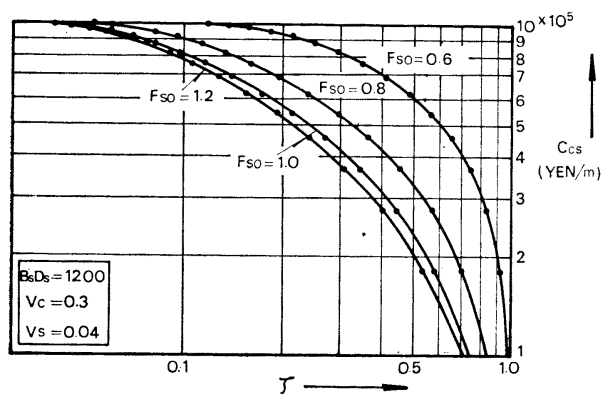

図一12 $C_{c s}$ と $\zeta$ の関係（地盤改良）

$C_{c s}=A_{s} \zeta^{B}+C_{s}$

表一1 の他のケースの場合にも, 基本的に同様の関倸 が確認された。したがって, 地盤改良をする場合の全建 設費と $と$ との関倸は次のようになる。

$$
C_{c}=C_{c 0}+C_{c s}=C_{c 0}+\left(A_{s} \zeta^{B_{s}}+C_{s}\right)
$$

これまでと同様, 例として示したケースに関する $A_{s}$, $B_{s}, C_{s}$ の計算結果を 表一3 に示した。

\section{（4）破壊損失費と破壊確率}

破壊損失費 $C_{F}$ とは，盛土が破壊した場合に生ずる損
失費である。したがって， $P_{F} C_{F}$ は，もしも確率 $P_{F}$ で 盛土が破壊したならば期待される損失費ということにな る。 $C_{F}$ の中には, 生じたすべり面の確認その他の目的 で実施される土質調査費 $C_{E r}$, 盛土の破壊による流出土 砂その他の整地費 $C_{a}$, 直接, 間接的な損害賠償費 $C_{r}$, また, 当初の所定断面まで盛土をつくり直す再建費, そ のための地盤改良費などが含まれる。前節までと同様, 各費用は，予想される盛土の破壊延長で除した単位長さ 当りの費用で表わす。

上記費用項目のらち， $\zeta$ の関数とならない費用 $C_{F 0}$ と関数となる費用 $C_{F 1}$ に分ける。 $C_{F 0}$ は一般に次のよ うになる。

$$
C_{F_{0}}=C_{c 0}+C_{r}+C_{E r}+C_{a}
$$

$C_{r}$ は盛土周辺の環境条件に依存するが，物件損害の場 合は原形復旧を原則とする。また，移転などの対策を含 み施工管理を厳重に行なって, 人命の損失がないように する立場をとる。 $C_{F 0}$ は盛土の単位長さ当りで表わす ので, $C_{r}$ を想定する場合, 被害の及ぶ範囲, 寸なわち, 盛土の破壊延長の推定が重要な問題となる。筆者らが実 施したアンケート調査や文献 21) によると, 盛土の破 壊延長は $50 \mathrm{~m}$ 前後の場合がほとんどで, 20 120 m の 範囲が観測されている。別に根拠はないが，平均的な場 合よりも少し大きく見積もって，80 m の長さで盛土が 破壊した場合の全損害賠償費を算出し，これを $80 \mathrm{~m}$ で 除した值を $C_{r}$ とすればよいと考えられる。調查費 $C_{E r}$ は, 盛土再建のための再設計に際する新しい破壊確率と 関連するから， $C_{F 0}$ の中に入れて考えるにはやや無理が ある。さらに, 当初建設の際の調查費が全建設費に占め る割合がたとえ小であったとしても, 破壊後の調查はよ り慎重を期すべきであるから当初の調查費よりももっと 多額の費用を要するかも知れない。したがって, $C_{E}$ と $\zeta$ の関数関係を明確にしていくことが，今後重要であ り, 当初調查によって得られた情報と破壊調査によって 得られる情報を組み合せて考察する必要がある。これに は Bays（ベイズ）の理論などが応用できると考えられ る。しかし，ここでは全体としての方法論を確立するこ とが主目的であることに加えて, これらの関数関係を明 確にするためのバックデーターが不足しているため, 一 応, 第一段階の便法として $C_{E r}$ を $\zeta$ に無関係の費用 $C_{F 0}$ に含めて考えることにする。

次に, $\zeta$ に関係する費用 $C_{F 1}$ は次式で与えられる。 $C_{F 1}=C_{c m}+C_{c p}+C_{c s}$

上式の右辺各項は前節までに説明したとおりである。た だし, 破壊後の地盤改良工法として砂杭工法が不適当と 考えられる場合, すなわち, たとえばすべり置換法が適 当と考えられるようなケースに対しては, 新しく $C_{c s}$ の 関数形を求める必要がある。な抣式 (24) で, ある工 
法，たとえば押え盛土を実施しない場合には $C_{c p}$ を省 略する。

全破壊損失費 $C_{F}$ は，式 (23)，(24）の和として求 められる。

$$
C_{F}=C_{F_{0}}+C_{F 1}
$$

\section{（5）簡単なまとめ}

前節までに得られた結果をまとめると，盛土の建設に 要する期待総費用 $C_{T}$ は次のようにかける。

$$
\begin{aligned}
C_{T}(\zeta)= & C_{E p}+C_{c 0}+C_{E}(\zeta)+C_{c m}(\zeta) \\
& +C_{c p}(\zeta)+C_{c s}(\zeta) \\
& +\zeta\left\{C_{F 0}+C_{c m}(\zeta)+C_{c p}(\zeta)+C_{c s}(\zeta)\right\}
\end{aligned}
$$

上式は, 考えられるすべての対策工を併用した場合の一 般式である。建設手段として採用しない工法があるとき には，上式からそれに対応する項を省けばよい。

さて，(1) 節で述べたように，費用関数の無次元化を 図るために $C_{T 0}$ を考える。 $C_{T 0}$ は， $m=1.25, n=n_{0}$ で 無処理状態の場合に相当するから, 式 (26) に扔いて, $C_{E}(\zeta=1.0)=C_{E n 0}, \quad C_{c m}(\zeta=1.0)=C_{c p}(\zeta=1.0)=C_{c s}$ $(\zeta=1.0)=0$ を適用することにより次のようになる。

$$
C_{T_{0}}=C_{E p}+C_{c 0}+C_{E n 0}+C_{F_{0}}
$$

式（27）で定義された $C_{T_{0}}$ を基準として，式（26）を かきなおすと，

$$
\left.\begin{array}{rl}
\frac{C_{T}(\zeta)}{C_{T 0}}=\eta(\zeta)=\alpha(\zeta)+\beta(\zeta) \\
\alpha(\zeta)= & \frac{1}{C_{T 0}}\left\{C_{E_{0}}+C_{c 0}+C_{E}(\zeta)+C_{c m}(\zeta)\right. \\
& \left.+C_{c p}(\zeta)+C_{c s}(\zeta)\right\} \\
\beta(\zeta)= & \frac{\zeta}{C_{T 0}}\left\{C_{F 0}+C_{c m}(\zeta)+C_{c p}(\zeta)+C_{c s}(\zeta)\right\}
\end{array}\right\}
$$

上式の $\eta(\zeta)$ は, 実際の使用に際して, 式 (1) で定義 した $C_{T}$ よりもはるかに一般性があり, 計算誤差も少な くできる。費用関数の無次元化の有利さについては, 前 に指摘した ${ }^{22)}$ 。

\section{4. 二, 三の数値計算例と実際例に関する検討}

\section{（1） 概 説}

はじめに二, 三の数值計算例を示したのち, 実際に施 工されたいくつかの例に対して前章の評価モデルを適用 し, 考えられる種々の代替案の中で, 実際に施工された 盛土がどの程度の適正さを有していたかを検討する。実 際例の中には, 何の事故もなく予定どおりに完成したも のもあれば，施工中にすべりを生じて地盤改良その他の 対策を講じっくり直したものもある。なお，ここで明確
にしておかなければならないことは次の点である。本論 文の主目的は，土質力学的な考察に裏付けられた費用関 数の決定であり,この目的は 3. で一応達せられた。し かし, 式 (28) の最適解を求める方法に関しては今後の 課題として残し，本論文では取扱っていない。そのた め, この章で比較されるいくつかの案は, 最適解を含む ものではなく，あくまでも，いくつかの代替案である。

\section{（2）数值計算例}

$F_{s 0}$ と $k_{p}$ の影響をみるために, $F_{s 0}=0.8,1.2$ 亿対 し, それぞれ農村部や都市近傍を想定して, $a_{c p}\left(=a_{c m}\right)$ を $3000,10000,40000\left(\right.$ 円 $\left./ \mathrm{m}^{2}\right)$ の 3 段階に分け, $b_{c p}$ $\left(=b_{c m}\right)$ は $200\left(円 / \mathrm{m}^{3}\right)$ として計算した。また, 損害賠 償費に関しては, 農産物補償による原形復旧と被害範囲 の土地買収の場合に分け, 合計 12 ケースの計算を行な った。前者については, 生産者米価を参考にし, 1 年間 の稲作収入を補償するとして計算した。また, 過去の実 績を参考にして, $C_{E p}$ は $200($ 円 $/ \mathrm{m}),\left(C_{E r}+C_{a}\right)$ は $C_{c 0}$ の $5.7 \%$ とした。図一13 は計算の結果である。図 -13(a) ( f ) が原形復旧，（g) が買収の場合である。計 算に用いた諸数值は，すべて図中に示してある。

結果を検討する際に重要なことは次の点である。本計 算では斜面勾配変化や押え盛土を実施する場合には，こ れに必要な土地は無制限に一定の地価で入手できるもの として計算している。しかし実際は, 無制限に土地を買 収できない事情があり，らの範囲には現実的な制約が加 わる。現在実施されている一般的な押え盛土の幅 $B^{\prime}$ や 斜面勾配 $m$ の現実的な最大值は, このような理由によ って定まっているものと思われる。したがって，結果の 考察にはこの点を考慮しなければならない。また, 筆者 らは $C_{T} \rightarrow \min$, 寸なわち $\eta(\zeta) \rightarrow \min$ を評価基準として 採用しているので, この観点から代替案の比較を行な う。

さて図において $\eta(\zeta)$ に付したサフィックス $E, m$, $p, s$ は, それぞれ追加調查, 斜面勾配変更, 押え盛土, 地盤改良を行ならことを意味する。たとえば， $\eta_{p}{ }^{s}(\zeta)$ は，もし破壊したら地盤改良を併用して再建する予定の もとに，押え盛土併用で盛土を建設する場合の $\eta(\zeta)$ の 值である。はじめに地価の影響をみてみる。図 (a), (d) をみれば明らかなように, 盛土建設地域の地価が高い場 合は, ここに示したいくつかの代替案の中では, $\eta(\zeta) の$ 大きさからみて当初地盤改良工法を用いるのが圧倒的に 有利である。このことは, 地価の高い場合は $p$ や $m$ の 案では用地費が非常に高くつくのに対し, 盛土直下の狭 、範囲で実効の上る $s$ の有利性を示すもので, きわめて 常識的な結果であるといえるであろら。なおこの場合, 砂杭改良工法の現実的な技術的制約条件，すなわち実 

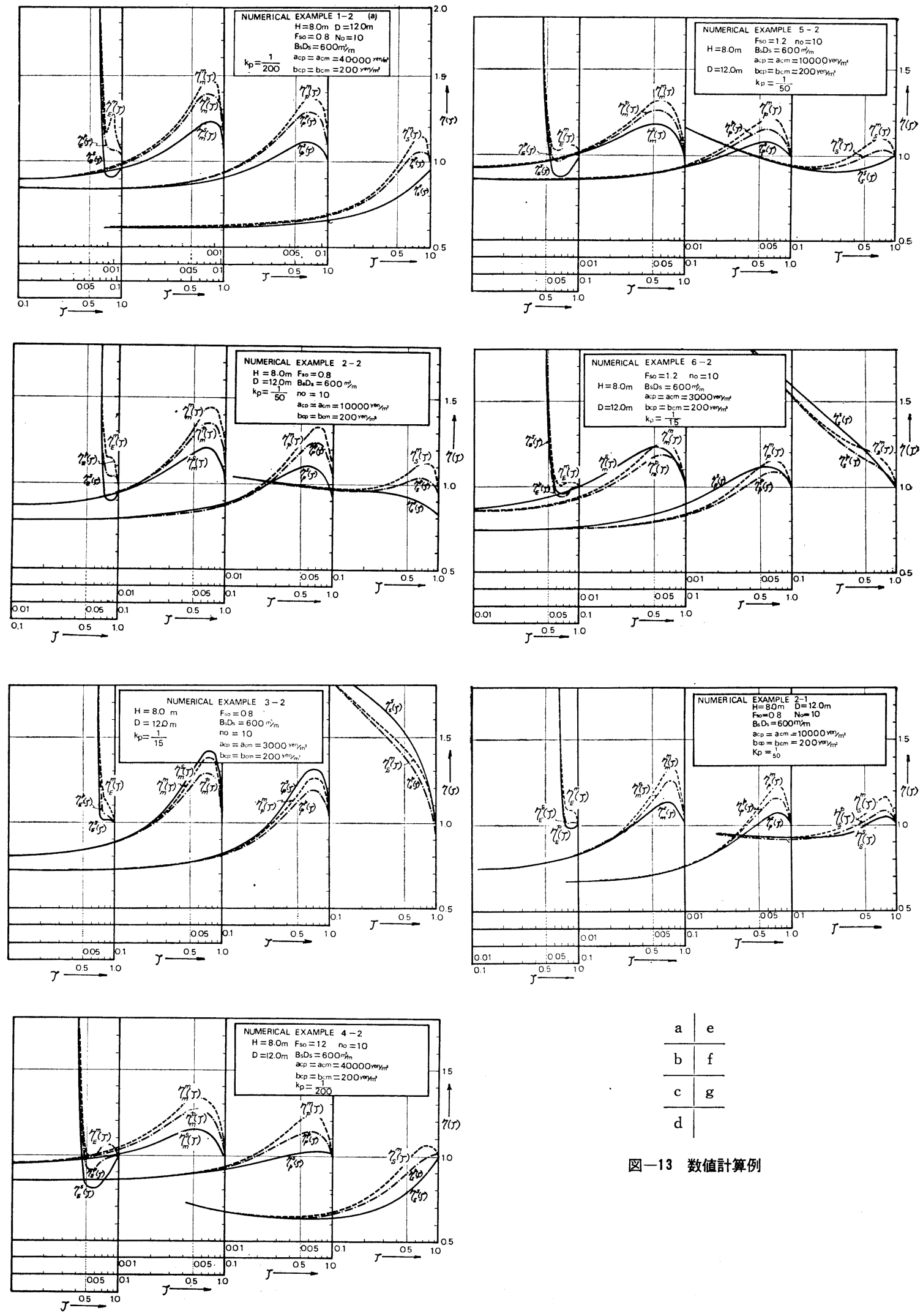

図-13 数值計算例 
績における $a_{s}$ の最大值 0.2 に対応する $\zeta$ の值は 0.04 0.05 であり, たとえば, $\eta_{s}{ }^{s}(\zeta=0.05) \doteqdot 0.62, \eta_{s}{ }^{s}(\zeta=$ $0.04) \fallingdotseq 0.64$, これに対応する $P_{F}, F_{s}$ は $P_{F}=4.91 \%$, $F_{s}=1.62$ ( $F_{s 0}=0.8$ の場合), $P_{F}=3.9 \%, F_{s}=2.11$ $\left(F_{s 0}=1.2\right.$ の場合) となる。一方, 地価が安い図 (c), (f) の場合になると, 初期建設段階で $s$ を用いるよりも, $p$ とか $m$ を用いた方が合理的になってくる。前述した $B^{\prime}, m$ の現実的な制約を考慮すると， $B_{\text {max }}^{\prime}=15 \mathrm{~m}$, $m_{\max }=3.5$ 程度と考えられ, これらに対応する れぞれ $0.45 \sim 0.60,0.74 \sim 0.86$ となる。この点を考慮 すると，ここにあげた例の中では， $p$ すなわち押え盛 土を初期段階で用いるのが最も有利となり， $F_{s 0}=0.8$ のときは $P_{F}=4.8 \%, F_{s}=2.00, F_{s 0}=1.2$ のときは $P_{F}=2.7 \%, F_{s}=2.38$ となる。また図 (b), (e) の場 合は, 上述の 2 つの場合の中間で, 各工法の有用さはか なり接近し, 環境条件を十分吟味して選択する必要のあ ることがうかがわれる。

次に, $F_{s 0}$ の影響をみるとき, 顕著な特徵は $\eta_{E}(\zeta)$ 曲線である。図 (a), (b), (c), と (e), (f), ( g ) を比較す ればわかるように, $F_{s 0}=0.8$ では $E$ による案, すなわ ち追加調査によって設計信頼度を上昇させるという案 は, 他の案に比べてまったく劣っているのが, $F_{s 0}=1.2$ の場合には他の案と同程度に有力な案として浮び上 ってくることがわかる。このことは，Eによって 期待できる安全率の上昇度が他の場合より小さいか ら $F_{s 0}$ 小のときには不利になるであろう, という 直観的な予想と一致する。

図（g）は，被害を受けた土地の買収費を見込む 場合の一例である。これを（a）と比較すると, 全 体の傾向はほとんど変わらないが， $\eta(\zeta)_{\min }$ に対す るらが少し減少してくる。すなわち, 図（a）でたと えば $\eta_{s}(\zeta)_{\min }$ に対する $\zeta$ は $0.15\left(P_{F}=11.7 \%\right.$ ， $\left.F_{s}=1.60\right)$ であるのに対し, 図 $(\mathrm{g})$ では $\eta_{s}(\zeta)_{\mathrm{min}}$ に対する $\zeta$ は $0.10\left(P_{F}=7.8 \%, F_{s}=1.74\right)$ に減 少することがわかる。このことは， $C_{F}$ を大きく見 込まなければならない盛土は, それだけ重要度が高 く， $F_{s}$ む大きくとるべきであることを意味してい る。

なお, 全体の傾向として注目すべき点は, 各代替 案の中で, いずれも最悪点ともいらべき点, すなわ ち設計として最もまずい選択が存在することであ る。何かして高い建設費をかけるなら，むしろ何も しない方がよい (無処理)ことがありらる点に注意 しなければならない。

\section{（3）実際例についての検討}

[例一1] : この実施例は, 計画盛土高 $6.0 \mathrm{~m}$, 天端
幅 $8.4 \mathrm{~m}$, 斜面勾配 1.5 で, 橋梁取付道路の盛土として 片側水田, 片側河川の場所に施工された。地盤は地表面 下 $12 \mathrm{~m}$ までが $\overline{c_{u}}=1.55\left(\mathrm{t} / \mathrm{m}^{2}\right)$ の軟弱粘土層で, その 下は $N>20$ の砂れき層である。計算によると $F_{s 0}=0.75$ となる。さてこの盛土は $4 \mathrm{~m}$ まで押え盛土なしに施工 され, これから $5 \mathrm{~m}$ にかけて盛上ってきたときに水田 側に浮上るすべりを生じたので，急遽，押え盛土を施工 $\left(B^{\prime}=8.0 \mathrm{~m}, H^{\prime}=3.0 \mathrm{~m}\right)$, 緩速盛土として圧密による 強度増加を見込みつつ $F_{s}=1.13$ で施工された。以上 の条件のもとに, 一応水田の地価を $a_{c p}=5000\left(\right.$ 円 $\left./ \mathrm{m}^{2}\right)$, $k_{p}=1 / 25$, 農産物補償と想定して, 前章のモデルで検討 した結果が 図一14 である。他の費用は, 実際に要した 費用をそのまま用いた。なおこの例では，河川側は擁壁 で留められているので, 式 (14), (17) の $C_{c m}, C_{c p}$ は それぞれ $1 / 2$ にして計算に用いた。現実の実施点を図に ・印で示してある。 $m, p$ の現実的な制約を考えると， 押え盛土を採用したことは適切であったといえるが，施 工中 2 度目のすべりを生じて, 結局地盤改良を実施せざ るをえなかったことを考慮すると，図中 $\eta_{p}^{s p}(\zeta)$ 曲線 上の実施点よりも $\eta_{p}^{p}(\zeta)$ 曲線上でもら少し $B^{\prime}$ を拡げ, らを下げておいた方がよりよかったのではないかと思わ れる。なお，押え盛土が片側だけであるので， $s$ が相対

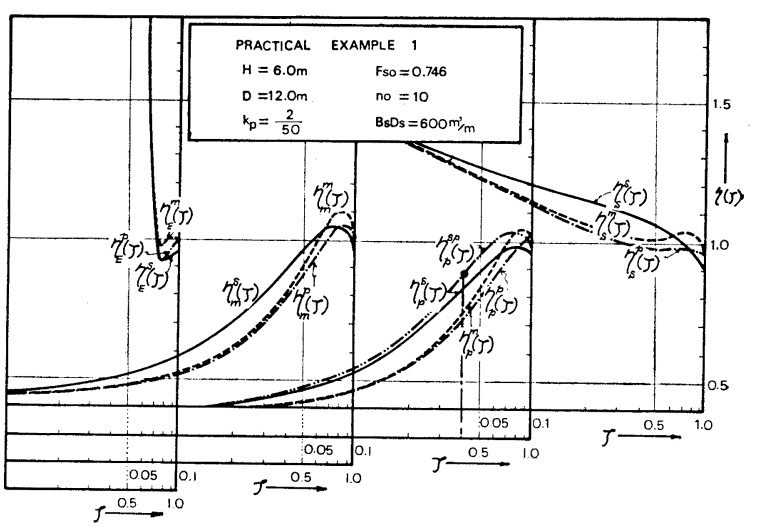

図-14 実施例-1

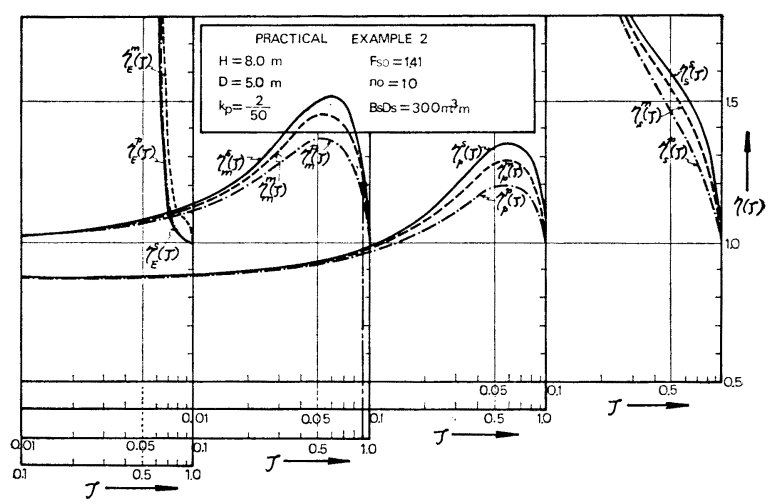

図-15 実施例一2 


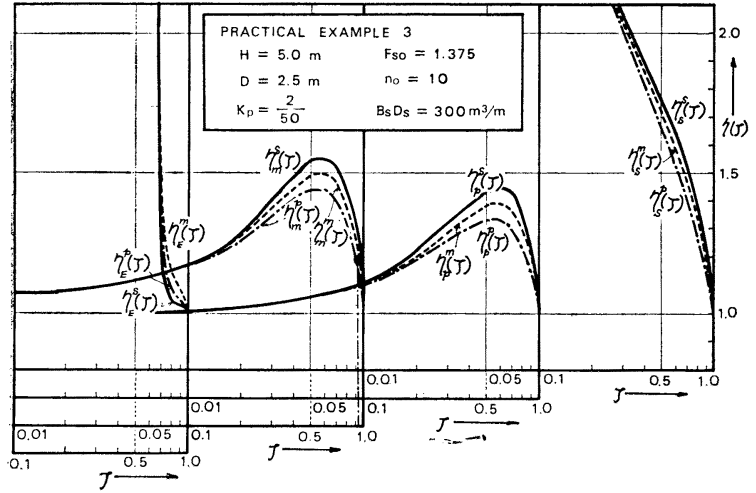

图-16 実施例-3

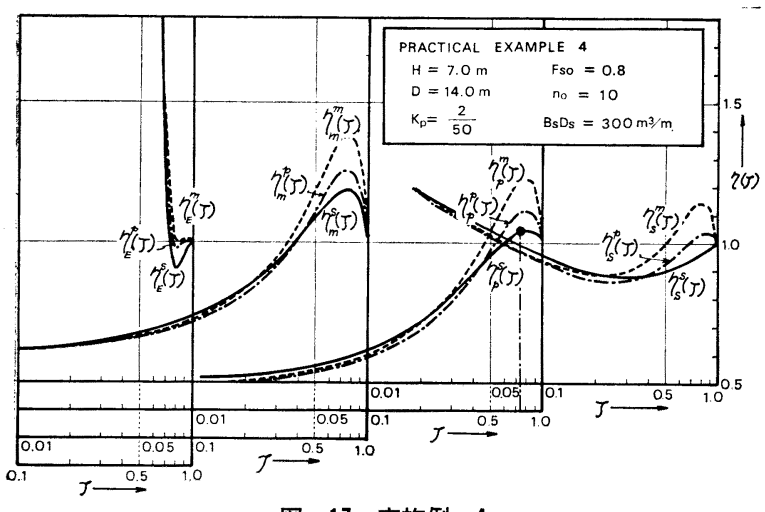

図-17 実施例-4

的に非常に高くつくのは当然の結果である。

[例一2]：やはり道路の盛土である。盛土高 $6.0 \mathrm{~m}$, 斜 面勾配 2.0 , 天端幅 $22.0 \mathrm{~m}$ で, 無事故で立上り現在供 用されている。無処理状態で $F_{s 0}=1.62\left(P_{F_{0}}=11.9 \%\right)$ である。地盤は, 地表面下 $2.5 \mathrm{~m}$ までが $\overline{c_{u}}=2.5\left(\mathrm{t} / \mathrm{m}^{2}\right)$ の粘土層で, それ以下は基盤層である。周囲は水田で, $a_{c p}=5000\left(\right.$ 円 $\left./ \mathrm{m}^{2}\right), k_{p}=1 / 25$, 農産物補償のケースで計 算した結果が 図一15 である。図から，斜面勾配をもう 少し急にして, 無処理状態に近づけた方がより経済的で あったと考えられる。また，実施点の上らに $F_{s}=1.65$ $\left(P_{F}=10.0 \%\right)$ までもっていくのであれば，土質試験を 追加して設計信頼度を上げる方がより効率的であったと 思われる。

[例一3] : この盛土は盛土高 $5.0 \mathrm{~m}$, 天端幅 $22.0 \mathrm{~m}$ で, 地盤は $2.5 \mathrm{~m}$ までが $\overline{c_{u}}=2.5\left(\mathrm{t} / \mathrm{m}^{2}\right)$ の粘土層で, それ以下は基盤である。計算によると $F_{s 0}=1.38$ であ り, 実際には $m=2.0$ として無事故で立上った。 $a_{c p}=$ $5000\left(\right.$ 円 $\left./ \mathrm{m}^{2}\right), k_{p}=1 / 25$, 農産物補償として計算した結果 を図一16 に示す。図からわかるように，この盛土の $\eta(\zeta)_{\min }$ は $\zeta=1.0$ で生じており, 斜面勾配をもっと急 にした方が経済的により有利であったといえる。

[例一4]：この盛土は水田の真中を通る道路盛土であ
り，実際にすべった例である。計画盛土高 $7.0 \mathrm{~m}$, 底面幅 $30.0 \mathrm{~m}$, 天端幅 $9.5 \mathrm{~m}$ で, 地盤は地表面下 $14 \mathrm{~m}$ までが $\overline{c_{u}}=2.0\left(\mathrm{t} / \mathrm{m}^{2}\right)$ の粘土層, その下が堅 い砂れき層であった。計算では $F_{s 0}=0.8\left(P_{F_{0}}=\right.$ 79.4\%）となり，これをもとに $\eta(\zeta)$ 曲線を描くと 図一17 のようになる。 $a_{c p}, k_{p}$, 補償形式はこれま でと同じにしてある。さて，用地が無限に買収可能 ならば，図からわかるように，识( $(\zeta)$ ，すなわち押 え盛土を実施するのが最良である。しかし，さきに 述べたように，用地買収にはおのずから限界がある からこれを $B^{\prime}=2.5 \mathrm{H}$ 程度と考えると, $\eta(\zeta)_{\text {min }}$ となるのは $\eta_{s}(\zeta)$ 曲線, すなわち地盤改良の場合 であることが明らかである。このとき なり， $P_{F}$ は $79.4 \%$ から $11.9 \%$ まで大幅に低下 させることが可能となるわけである。な㧍，実際に は, 押え盛土を併用して $\zeta=0.74\left(F_{s}=0.94, P_{F}=\right.$ $74.6 \%)$ で施工しており，これが適正でなかったこ とは図から明らかである。

\section{5.むすび}

粘土地盤上の盛土の合理的な設計安全率決定法に 関し, 力学的な破壊確率と経済的な評価との関連を もとに考究した。3. で尊いた費用関数，すなわち， 土質力学と確率論的考察に基づいて得られる破壊確 率を仲介にして, 結果的に, 盛土建設に際する期待総費 用と設計安全率の関係を明確にしたのが, 本研究の主要 な成果である。

4. で試みた数值計算例や実施例の検討において, 経 済的モデルによる結果が, 常識的推測ときわめてよく一 致することが明らかとなった。

終りにあたり，盛土の破壊その他に関するアンケート 調查に解答下さった方々および貴重なる資料を提供して 下さった関倸各位に深く感謝いたします。

\section{参考文献}

1) Freudenthal, A.M. : The Safety of Structures, Proc. ASCE, Vol. 71, pp. 1157 1191, 1945.

2) Freudenthal, A.M. : Safety and the Probability of Structural Failure, Proc. ASCE, Vol. 80, pp. 468-1 468-46, 1954

3）浅田秋江・松尾稳・湯浅欽史・羅文鵠：土質工学化抄ける 安全率に対する反省, 第 12 回土質工学シンポジウム発表 論文集, pp. 51 74,1967.

4）松尾 稔・黑田勝彦: 盛土建設のための土質調査と 盛土 の安定性に関する研究, 土木学会論文報告集, 第 196 号, pp. $75 \sim 86,1971$

5）松尾 稔・黑田勝彦：盛土の破壊確率を考虑した土質調 查の規模决定法について, 土木学会論文報告集, 第 198 号, pp. $69 \sim 81,1972$

6）堂垣内尚弘：道路の路肩と法面, 理工図書, pp. 83 89 1961 
7）土木学会 : 土木工事の積算, pp. 10 12, 1970

8）土木学会: 土木学会誌, Vol. 55, 1 (積算特集号)，1970

9) Hooper, J.A. and Butler, F.G. : Some Numerical Results Concerning the Shear Strength of London Clay, Geotechnique, Vol. 16, pp. 282 304,1966

10) Lumb, P. : The Variability of Natural Soils, Canadian Geotechnical Journal, Vol. III, No. 2, pp. 74 97,1966 .

11) Lumb, P.: Safety Factors and the Probabity Distribution of Soil Strength, Canadian Geotechnical Journal, Vol. 7, No. 3, pp. 225 242,1970.

12) Meyerhof, G.G. : Safety Factors in Soil Mechanics, Canadian Geotechnical Journal, Vol. 7, No. 4, pp. $349 \sim 355,1970$.

13）土地政策研究委員会 : 日本の土地問題, 第 1 部, 経済企 画協会, pp. 132 139,1970.

14）松尾 稔：砂ぐいを打設した粘土地盤の安定計算につい て, 土之基礎, Vol. 15, No. 12, pp. 27 35,1967.

15）松尾 稔: 複合地盤の支持力に関する研究 (その 3 ), 土
と基礎, Vol. 17, No. 2, pp. 5〜11 1969.

16）中山二郎・一本英三郎・上田 茂：バイブロコンポーザー 工法の盛土基礎地盤スベリ破壊防止効果について，第 15 回土質工学シンポジウム発表論文集, pp. 81 86,1970

17）石井靖丸：軟弱地盤工法, 技報堂, 1963

18）松尾 稔：引揚力を受ける基礎と複合地盤の支持力に関 する研究, 京都大学提出学位論文, pp. 191 211,1969.

19）不動建設研究室：コンポーザーシステムデザインマニュ アル, Vol. 2 (1972 年発行予定)

20）経済調査会: 積算資料, No. 488, 経済調査会出版部, p. 31,1971 .

21）建設省土木研究所: 土木研究所資料, 第 635 号, 軟弱地: 盤における盛土の破壊例集, 1970

22) Nagao, Y. and Kanai, M. : A Study on the Method. of Port Improvement by Physicacal Distribution Cost Analysis, 22 nd Int. Navigation Cong., S.I.-1, pp. $1 \sim 23,1969$.

(1971.11.1 · 受付) 